Revista de BIOLOGía TROPICAL

\title{
Can anthropic fires affect epigaeic and hypogaeic Cerrado ant (Hymenoptera: Formicidae) communities in the same way?
}

\author{
Ernesto de Oliveira Canedo-Júnior ${ }^{1,3^{*}}$, Rafael Gonçalves Cuissi ${ }^{1,2}$, Nelson Henrique de Almeida \\ Curi $^{2}$, Guilherme Ramos Demetrio ${ }^{2}$, Chaim José Lasmar ${ }^{1,2}$, Kira Malves ${ }^{2}$ \& \\ Carla Rodrigues Ribas ${ }^{1}$ \\ 1. Laboratório de Ecologia de Formigas, Setor de Ecologia e Conservação, Departamento de Biologia, Universidade \\ Federal de Lavras, Lavras, MG, CEP: 37200-000, Brazil; crribas@gmail.com \\ 2. Programa de Pós-graduação em Ecologia Aplicada, Universidade Federal de Lavras, Lavras, MG, CEP: 37200-000, \\ Brazil; rafaelcuissi@gmail.com,nelsoncuri@hotmail.com, gramosdemetrio@gmail.com, chaimlasmar@gmail.com, \\ kiramalves@gmail.com \\ 3. Programa de Pós-graduação em Entomologia, Universidade Federal de Lavras, Lavras, MG, CEP: 37200-000, \\ Brazi1*; canedojr.e.o@gmail.com
}

\section{Received 27-II-2015. Corrected 25-VIII-2015. Accepted 30-IX-2015.}

\begin{abstract}
Fire occurrences are a common perturbation in Cerrado ecosystems, and may differently impact the local biodiversity. Arthropods are one of the taxa affected by fires, and among them, ants are known as good bioindicators. We aimed to evaluate the effect of anthropic fires on epigaeic and hypogaeic ant communities (species richness and composition) in Cerrado areas with different post-fire event recovery periods. We conducted the study in four Cerrado areas during two weeks of 2012 dry season: one unburned and three at different post-fire times (one month, one and two years). We sampled ants with pitfall traps in epigaeic and hypogaeic microhabitats. We collected 71 ant morpho-species from 25 genera. In the epigaeic microhabitat we sampled 56 morpho-species and 42 in the hypogaeic microhabitat. The area with the shortest recovery time presented lower epigaeic ant species richness $(4.3 \pm 2.00)$ in comparison to the other areas $(8.1 \pm 2.68$ species on one year area; $10.3 \pm 2.66$ species on two years area; $10.4 \pm 2.31$ species on control area), but recovery time did not affect hypogaeic ant species richness. Regarding ant species composition, fire did not directly affect hypogaeic ant species, which remained the same even one month after fire event. However, two years were not enough to reestablish ant species composition in both microhabitats in relation to our control group samples. Our study is the first to assess anthropic fire effects upon epigaeic and hypogaeic ants communities; highlighting the importance of evaluating different microhabitats, to more accurately detect the effects of anthropic disturbances in biological communities. We concluded that ant communities are just partially affected by fire occurrences, and epigaeic assemblages are the most affected ones in comparison to hypogaeic ants. Furthermore the study provides knowledge to aid in the creation of vegetation management programs that allow Cerrado conservation. Rev. Biol. Trop. 64 (1): 95-104. Epub 2016 March 01.
\end{abstract}

Key words: anthropic burning, brazilian savannah, post-fire recovery, conservation, bioindicators.

The Brazillian Savanna (Cerrado) is a biodiversity hotspot presenting many endemic species (Myers, Mittermeier, Mittermeier, Fonseca, \& Kent, 2000). Its vegetation can be characterized by sparse trees and continuous grassy fields and is influenced by seasonal rainy periods and various disturbances, with fire figuring as the major one (Huntley \& Walker, 1982).
Natural fires are common in the Savannas, chiefly caused by lightning reaching small patches in the rainy season (Ramos-Neto \& Pivello, 2000), and have great importance in community dynamics maintenance in this biome (Townsend, Begon, \& Harper, 2010). Fire can be considered one of the factors that allow the balance between tree and grass density, 
maintaining the main features of savanna vegetation (Higgins, Bond, \& Trollope, 2000).

Biological communities of savannas are widely adapted to fire action, having great resistance and resilience to this disturbance. This fact can be attributed to plant characteristics such as accumulation of below ground biomass (Castro \& Kauffman, 1998), seed germination stimulated by fire (Raven, Evert, \& Eichhorn, 2007) and physiologic adaptations that ensure lower mortality (Hoffmann, Orthen, \& Nascimento, 2003).

However, most burning in the Brazilian Savanna (Cerrado) is not natural, it is caused by farmers intending to clean areas for agriculture or pasture (Mistry, 1998; Rivera-Lombardi, 2003). The anthropic fires usually occur in the dry season (Pivello, 2011). They may present an increase in probability occurrence (being more frequent and intense than natural fires), due to the increase in human activity, the proximity with human activity indicators, such as road systems and previously burned areas (Pereira, França, \& Santos, 2003), and the occurrence of dry years. Another important factor driving anthropic fire occurrence is the introduction of exotic grasses that may cause a fast accumulation of inflammable biomass, enhancing fire occurrence (Cianciaruso, Silva, \& Batalha, 2009). Changes caused by anthropic fires can affect animals in many ways, driven not only by the species sensitivity to the impact, but also by the fire intensity, frequency, and extension, allied to the proximity to unburned areas (Frizzo, Bonizário, Borges, \& Vasconcelos, 2011).

Mainly in Savanna areas, an increase in fire frequency may affect several animal taxa such as arthropods (Swengel, 2001; Vasconcelos et al., 2009) small mammals (Kelly et al., 2011; Andersen, Woinarski, \& Parr, 2012) and reptiles (Valentine \& Schwarzkipf, 2009), decreasing their richness and abundance.

To monitor the changes caused by fires, bioindicators have been used as a diagnostic tool to assess the impacts of human activities (Niemi \& McDonald, 2004). Among the groups used for bioindication, insects offer faster responses, supporting an early diagnosis of the environment (Schowalter, 2006). In this context, ants are considered reliable indicators for several disturbances (Underwood \& Fisher, 2006; Philpott, Perfecto, Armbrecht, \& Parr, 2010; Ribas, Campos, Schmidt, \& Solar, 2012), including fire, because such an impact may alter ant species richness (Andersen, Hertog, \& Woinarski, 2006), composition (Silveira et al., 2013), and dominance (Andersen, 1991; Parr \& Andersen, 2008).

Therefore, the aim of this study was to assess the impact of the environmental disturbance caused by anthropic fire over the Epigaeic and Hypogaeic ant community in areas with different recovery times. For this purpose we tested the following hypotheses: a) ant species richness is higher in areas with higher post-fire recovery times, b) ant communities from older recovery time areas show more similarity with communities from unburned areas and c) fire effects upon ant richness and composition are more evident in epigaeic microhabitats than hypogaeic microhabitats. Moreover, we verified the influence of environmental variables (ant resources and conditions) on ant species richness and composition, and also assessed the presence of indicator species for each fire recovery stage and unburned areas.

\section{MATERIAL AND METHODS}

Study area: The study was conducted at the Sumidouro State Park, located among the municipalities of Lagoa Santa, Pedro Leopoldo and Matozinhos, Minas Gerais State, Brazil

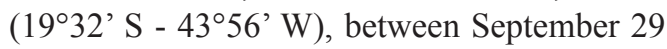
and October 13, 2012 in four Cerrado areas. Three of them were in different recovery times after intentional fire (one month, one year and two years) and the fourth area (with no documented fire occurrence at least in the last 5 years) was used as control.

Ant collection: We established a $200 \mathrm{~m}$ transect in the middle of each area, and installed 10 sampling points at uniform intervals of $20 \mathrm{~m}$ (Cheli \& Corley, 2010; Guimarães, Lasmar, Querido, Tanure, \& Ribas, 2014; Vasconcelos 
et al., 2014; Rabello et al., 2015). At each point we installed two pitfall traps, in each pitfall trap we placed $200 \mathrm{ml}$ of solution of water, detergent $(0.6 \%)$ and salt $(0.4 \%)$. One trap was placed in the epigaeic microhabitat and other in the hypogaeic (for trap details see Bestelmeyer et al., 2000; Schmidt \& Solar, 2010). All traps remained in the field for 96 hours. After collection, ants were taken to the Universidade Federal de Lavras (UFLA) Ant Ecology Laboratory, where they were sorted and identified to the genus level according to Fernández (2003). This procedure was followed by morpho-speciation according to the repository acronym of the Ant Ecology Laboratory.

Environmental data collection: The following measures were used as environmental variables: canopy cover, soil herbaceous layer cover, herbaceous richness, soil moisture and temperature, litter heterogeneity and thickness, and soil compression.

At each sampling point we calculated the canopy cover with a digital camera equipped with a fish-eye lens. The images were analyzed with the Gap Light Analyser software providing the percent of plant cover (Frazer, Canham, \& Lertzman, 1999).

For the soil herbaceous cover estimate we visually estimated the percentage of herbaceous cover within a $1 \times 1 \mathrm{~m}$ plastic square placed next to the sampling points. We also counted the different herbaceous morpho-types to estimate their species richness (adapted from Cardoso, Crispim, Rodrigues, \& BarioniJúnior, 2003).

For soil moisture and temperature we used a digital thermo-hygrometer introduced into the soil surface layer. To assess litter heterogeneity we placed a $25 \times 25 \mathrm{~cm}$ square next to the sampling points, and estimated the amount of different items found (leaves, flower, seeds, etc). Then we calculated the Shannon diversity index for each point (Queiroz, Ribas, \& França, 2013; Lucas Paolucci, pers. comm.). For litter depth measuring, we used a ruler introduced down to the soil level. To estimate soil compression we dropped an acuminate object from
$1.5 \mathrm{~m}$ from the soil, and its penetration was measured with a ruler.

Data analysis: In order to assess differences in species richness among areas at different post-fire recovery times and in the unburned areas, we used generalized linear models (GLM) for each microhabitat that was developed in $\mathrm{R} 2.15 .1$ software ( $\mathrm{R}$ Core Team, 2013).

To identify differences in ant species composition in each microhabitat and assess similarity among areas, we performed a similarity analysis (ANOSIM) with PRIMER 6 in each microhabitat, taking in account the presence/ absence of species.

To assess if the effect of fire is most evident in litter than in underground microhabitats, we compared the fire effects on species richness and composition between the two microhabitats studied (epigaeic and hypogaiec). For this we used results of the above analyses regarding species richness and composition.

To verify the independent effects of environmental variables on ant species richness in each microhabitat, we used hierarchical partitioning (Chevan \& Sutherland, 1991). Models were built with Poisson error distribution, since such distribution is appropriate for count data, using R 2.15.1 (R Core Team, 2013). Significance of independent effects was obtained after 500 randomizations. We used multivariate analysis based on distances for linear models (DISTLM) with Jaccard similarity index, to point out a possible relationship between ant composition and environmental variables.

We used the IndVal (Indicator Species Analysis) (Dufrêne \& Legendre, 1997) in order to point out indicator species of post-fire recovery and unburned areas. Those species with over $70 \%$ (characteristic species) were considered indicator species, and those between 45 and $70 \%$ (detector species) were considered as with indication value (MacGeoch, Rensburg, \& Botes, 2002). Significances were obtained by the Monte Carlo test with 499 randomizations, using the software PC-ORD 5.1. 


\section{RESULTS}

In total we collected 71 ant morphospecies from 25 genera. In the epigaeic microhabitat we sampled 56 morpho-species and 42 in the hypogaeic microhabitat. Camponotus (Mayr, 1861), and Pheidole (Westwood, 1839) were the genera with the highest number of species (10 species each), followed by Solenopsis (Westwood, 1840) (seven species).

In the epigaeic microhabitat the one month post-fire area showed the lowest species richness $\left(\mathrm{F}_{2,37}=5.029 ; \mathrm{p}=0.005\right)$. The areas with one and two years of recovery times, and also the unburned area did not differ among each other $\left(F_{2,37}=0.638 ; p=0.430 ;\right.$ Fig. 1$)$. In the hypogaeic microhabitat, species richness did not differ among the sampled areas $\left(\chi^{2}=0.151\right.$ $\mathrm{p}=0.141)$. None of the environmental variables influenced ant species richness in the two microhabitats analyzed.

Epigaeic ant species composition was different among all the analyzed areas $(\mathrm{R}=0.429$; $\mathrm{p}=0.001)$. The area with the highest post-fire recovery time (two years) was more similar to the unburned area (Table 1). Variables influencing epigaeic species composition were litter heterogeneity $(\mathrm{p}=0.008$; Prop, proportion of the variance explained $=4.500)$, herbaceous cover $(\mathrm{p}=0.02$; Prop $=4.300)$, litter

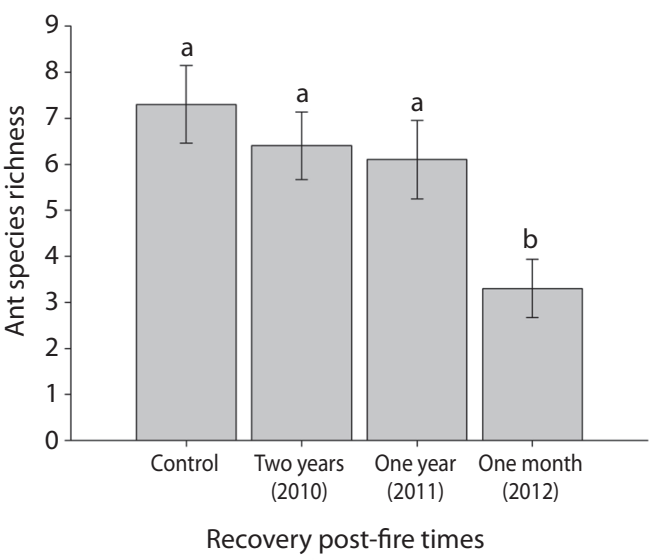

Fig. 1. Epigaeic ant species richness in areas with different recovery post-fire times $\left(\mathrm{F}_{2,37}=5.029 ; \mathrm{p}=0.005\right)$. Control $=$ unburned areas. Bars are standard errors. Different letters indicate different means in contrast analysis.

depth $(\mathrm{p}=0.03$; Prop=3.990) and temperature $(\mathrm{p}=0.04$; Prop=3.840).

Hypogaeic ant species composition also differed among all areas $(\mathrm{R}=0.189 ; \mathrm{p}=0.001)$, except in the comparison between one month post-fire and unburned area $(\mathrm{R}=-0.016 ; \mathrm{p}=0.521$; Table 1). Ant species composition in one year post-fire area was more similar to the unburned area (Table 1). Environmental variables that influence hypogaeic species composition were soil compression $(\mathrm{p}=0.014 ; \quad$ Prop $=4.960)$,

TABLE 1

ANOSIM results of epigaeic and hypogaeic ant species composition among sampled areas

\begin{tabular}{cccc} 
Areas $^{1}$ & Microhabitats & R values & p values \\
$2012 / 2011$ & Epigaeic & 0.586 & 0.001 \\
$2012 / 2010$ & Epigaeic & 0.339 & 0.002 \\
$2012 /$ Cont & Epigaeic & 0.409 & 0.002 \\
$2011 / 2010$ & Epigaeic & 0.468 & 0.001 \\
$2011 /$ Cont & Epigaeic & 0.555 & 0.001 \\
$2010 /$ Cont & Epigaeic & 0.279 & 0.001 \\
$2012 / 2011$ & Hypogaeic & 0.194 & 0.022 \\
$2012 / 2010$ & Hypogaeic & 0.280 & 0.003 \\
$2012 /$ Cont & Hypogaeic & -0.016 & 0.521 \\
$2011 / 2010$ & Hypogaeic & 0.411 & 0.001 \\
$2011 /$ Cont & Hypogaeic & 0.115 & 0.05 \\
$2010 /$ Cont & Hypogaeic & 0.266 & 0.002 \\
\hline
\end{tabular}

1. 2012, 2011 and 2010 - one month, one and two years post-fire recovery time, respectively. Cont - unburned control area.

2. The higher the $\mathrm{R}$ value $=$ the higher the dissimilarity among areas. 
TABLE 2

Indicator ant species for sampled areas

\begin{tabular}{lccc}
\multicolumn{1}{c}{ Morphospecies } & Area $^{1}$ & Indication Value (\%) & p values \\
Camponotus sp.2 & 2012 & $49^{* *}$ & 0.0028 \\
Camponotus rufipes & 2011 & $71.1^{*}$ & 0.0004 \\
Carebara sp. 1 & 2010 & $47.6^{* *}$ & 0.0018 \\
\hline
\end{tabular}

1. 2012, 2011 and 2010 - one month, one and two years post-fire recovery time respectively.

* Characteristic species: indication value greater than $70 \%$;* Detector species: indication value between 40 and $70 \%$.

temperature $(\mathrm{p}=0.003$; Prop $=5.920)$, herbaceous richness $(p=0.036$; Prop $=4.750)$ and litter depth $(\mathrm{p}=0.009$; Prop $=5.610)$.

Within the group of indicator species, one ant species was pointed out as characteristic (Camponotus rufipes (Fabricius, 1775)) of one year post-fire and two species as detector, one of one-month post-fire (Camponotus sp. 2) and other of two years post-fire (Carebara sp. 1, Table 2).

\section{DISCUSSION}

Our study assessed the response of the ant community to anthropic fire over two years of recovery and showed that with one month of recovery the epigaeic species richness is strongly affected, but one year is enough for full recovery of species richness. Hypogaeic species richness was not affected by fire. For epigaeic ant species composition, two years post-fire were not enough to restore species composition found in the unburned area. On the other hand, for hypogaeic ant species composition one month post-fire presented no difference to the unburned area, however areas with one and two years after fire had differences in species composition in comparison with the unburned area.

Epigaeic ant richness did not show a gradual increase in ant richness with an increase in post-fire recovery time as postulated in our first hypothesis. However, the youngest post-fire area (one month) showed the lowest richness. The pattern found for the youngest area can be attributed to the action of fire on local fauna, whether directly, through deaths or indirectly, through abrupt changes in local resources and conditions, which leads to an immediate drastic decrease in species richness in recently burned areas (Moretti, Duelli, \& Obrist, 2006). Nevertheless, the savanna vegetation presents adaptations to fire such as the accumulation of below ground biomass (Castro \& Kauffman, 1998), which allows fast regeneration of lost aerial parts. Furthermore, fire may stimulate seed germination (Raven et al., 2007), increasing habitat complexity. Such traits permit fast re-colonization by ant species, since in one year of recovery the burned area already showed species richness similar to unburned areas.

In the same way, other studies corroborate our results, since they show an immediate decrease in species richness and fast re-colonization in a short post-fire recovery period (Teixeira, Schoereder, Nascimento, \& Louzada, 2005; Rodrigo \& Retana, 2006; Parr \& Andersen, 2008). This observation is in agreement with the high resilience of the savannas which quickly restructures and thus permits other individuals to re-colonize (Huntley \& Walker, 1982).

Other studies conducted in a rain forest (Silveira et al., 2013) and temperate forest (Arnan, Rodrigo, \& Retana, 2006) did not show differences in epigaeic ant species richness between burned and unburned areas. This can be attributed to the resistance of some species to fire and the fast colonization by other species (frequently opportunistic generalists) in recently burned areas. Andersen et al. (2006), assessing the effects of fire on the ant community in savannas, found higher ant species richness in burned areas due to longer post-fire 
intervals (23 years), and influence of surrounding plant types and landscape characteristics.

Hypogaeic ant richness did not show differences among all sampled areas. Soil probably acts as a protection barrier facing fire disturbance, thereby resulting in less ant mortality compared with epigaeic ants. Schmidt, Ribas, and Schoereder (2013) suggested that hypogaeic ant species richness is affected only when disturbance drastically changes soil conditions. The fact of savanna vegetation maintaining a live root system below ground after fire disturbances (Castro \& Kauffman, 1998), allows resource and condition permanence, ensuring survival of the hypogaeic ant community without major losses of species.

None of the environmental variables tested showed significant influences on the epigaeic and hypogaeic ant richness, even they are commonly pointed to as important to ants (Arnan et al., 2006; Pacheco \& Vasconcelos, 2012; Queiroz et al., 2013; Schmidt et al., 2013). Another important factor that could be responsible for these environmental variables not regulating ant species richness is the anthropic interference caused by cattle, and the proximity with urban areas and rural roads observed in our studied area. These factors together could be more important in influencing ant species richness than the environmental variables measured, because they directly affect local fauna.

Ours results about species composition concerning epigaeic ants support our hypotheses. Despite species richness in burned areas becoming similar to unburned areas in a short time period (one year), the colonization in this area should be by generalist species, typically found in disturbed habitats (Cerdá, Arnam, \& Retana, 2013), making the return to the pre-fire species composition slow (Rodrigo \& Retana, 2006). Furthermore, our results point out that two years of recovery time are not enough to allow the return to pre-fire epigaiec ant species composition.

Another fact that may have influenced in the slow return of pre-fire epigaeic ant species composition is the anthropic influence, as already mentioned. Human actions, such as weed management, introduction of cattle and horses, and opening of roads and construction, may strongly affect local fauna, since the environmental variables analyzed had low explanatory power $(27.1 \%$ of the variance explained) for the species composition in sampled areas. As already mentioned for the regulation of ant species richness, constant impacts caused by anthropic actions may mask the real importance of tested variables, since these measures are also commonly documented as important in the determination of ant species composition (Arnan et al., 2006; Pacheco \& Vasconcelos, 2012; Queiroz et al., 2013; Schmidt et al., 2013).

Although hypogaeic ant species composition differs among most sampled areas, which may be related to transformations occurring in the successional process, the area with one month and the unburned area did not differ. Epigaeic ants suffer immediately with fire, because plant aerial parts can be burned immediately transforming the entire habitat. On other hand, in the hypogaeic microhabitat alterations caused by fire did not directly affect the community that may remain, as in the unburned areas, even one month after fire. Scherber et al. (2010) showed that the plant biodiversity alteration (e.g. by fire) has a strongly negative effect on organisms, but its effect is attenuated in below-ground organisms or these organisms may respond slowly to this alteration. Although areas with one and two year post-fire species composition were dissimilar to unburned area, this fact can reflect indirect effects of fire, since alterations occurred above ground, such as incorporation of organic matter and death and regrowth of vegetation, are what may have favored the colonization by other species.

The succession process in one and two years post-fire areas are reflected in environmental variables pointed as important features in the regulation of hypogaeic ant species composition, because they may cause changes in below ground systems, mainly transformations in the soil physical structure caused by regenerating plant roots (van Breemen \& Finzi, 1998), and may generate adequate environments for 
ant colonization. Moreover, higher plant diversity in the soil surface may provide high litter deposition; this fact regulates soil conditions (such as temperature and moisture), making the habitat favorable to ant foraging and with more resources and better conditions, supplying food and nesting resources for ants.

Regarding our hypotheses about the fire effects upon ant richness and composition being more evident in an epigaeic microhabitat than a hypogaeic microhabitat, we showed that for the hypogaeic ant community the soil surface acts as a protective barrier from the immediate effects of the fire. Differently, the epigaeic ant community is directly exposed to fire damage, causing the death or flight of the entire epigaeic ant community.

We did not find any indicator species of unburned areas, therefore we cannot point out if the recovery areas are really becoming recovered or this fact can be explained by the conservation status of the Park as whole, since it has a history of anthropic disturbance, independent of fire. Furthermore, both, species characteristic of the environment (Camponotus rufipes) and the two detector species (Camponotus sp. 1 and Carebara sp. 2), indicate that the studied areas are disturbed, since these species are commonly found in disturbed areas. The Park area is very close to urban areas, one of the reasons for the high frequency of fires with anthropic origin within its borders. Such proximity influences the species pool from both burned and unburned areas, a fact observed in indicator ant species of each area. Ants from the genera Camponotus (indicators of areas burned in 2011 and 2012) contains species with very diverse ecological traits, a fact that places the genera as the most distributed worldwide, occurring in almost all habitats (Wilson, 1976). For the 2010 area (two years old) one of the indicator species was from the genera Carebara (Westwood, 1840), related to environments in early successional stages (Silva, Feitosa, \& Eberhardt, 2007).

Several studies corroborate our results about the effect of fire on ant species composition, since all show significant differences in species composition between burned and unburned areas (e.g. Teixeira et al., 2005; Arnan et al., 2006; Andersen et al., 2006; Parr \& Andersen, 2008). Therefore, we believe that ant species composition is the most important parameter when evaluating the efficacy of post-fire recovery programs for biodiversity conservation. Silveira et al. (2013) showed that for evaluating fire disturbance, ant species composition is a more reliable parameter than species richness. This fact can be explained because ant species richness is less senstive to some disturbances (Ribas et al., 2012) and richness measures, in general, are more influenceable by sampling efforts (Barlow et al., 2007).

Our study is the first to assess anthropic fire effects upon epigaeic and hypogaeic ants, showing that hypogaeic ants are not directly affected by fire, as occurs in the epigaeic microhabitat. Ours results highlight the importance of evaluating different microhabitats to more accurately detect the effects of disturbances on biological communities. However, more studies are necessary to elucidate the effects of different burning regimes, used in savanna vegetation management, on biological communities over the long term. Such knowledge is important because it shows the average time needed for areas to reestablish after fire, allowing the creation of vegetation management programs similar to natural patterns, bringing together development of human communities from the Cerrado and the conservation of biological diversity in these areas.

\section{ACKNOWLEDGMENTS}

We thank IEF-MG for allowing the ant sampling and the employees and manager of the park, who provided information about sampled areas, Graziele Santiago for help in ant identification, and Antônio Queiroz for statistical analysis help. Ernesto OCJ, Nelson HAC and Guilherme RD are funded by CAPES, Rafael GC and Chaim JL are funded by Fapemig. 


\section{RESUMEN}

¿Pueden los incendios afectar a las comunidades de hormigas epígeas e hipógeas (Hymenoptera: Formicidae) de Cerrado de la misma manera? Los incendios son una alteración común en los ecosistemas del Cerrado brasileño y pueden causar diferentes efectos sobre la biodiversidad. Los artrópodos son uno de los taxones comúnmente afectados por el fuego, y entre ellos, se conoce que las hormigas son buenos bioindicadores. El objetivo de este trabajo fue evaluar el efecto de los incendios antrópicos sobre las comunidades de hormigas epígeas e hipógeas (riqueza de especies y composición) en áreas del Cerrado en diferentes tiempos de recuperación. Para ello, el estudio se realizó en cuatro áreas del Cerrado durante la temporada seca del 2012: una área no quemada y otras tres áreas en diferentes momentos post-incendio (un mes, uno y dos años). Las hormigas fueron muestreadas utilizando trampas de caída en los microhábitats epígeo e hipógeo. Fueron recolectadas 71 morfo-especies de hormigas pertenecientes a 25 géneros. En el microhábitat epígeo recolectamos 56 morfo-especies y en el microhábitat hipógeo 42. El área con el menor tiempo de recuperación presentó una menor riqueza de especies de hormigas epígeas $(4.3 \pm 2.00)$ en comparación con las otras áreas $(8.1 \pm 2.68$ especies en el área de un año; $10.3 \pm 2.66$ especies en el área de dos años; $10.4 \pm 2.31$ especies en el área de control), pero el tiempo de recuperación no afectó riqueza de especies de hormigas hipógeas. En cuanto a la composición de especies, el fuego no afectó directamente a las especies de hormigas hipógeas, la cual se mantuvo igual, incluso un mes después del incendio. Sin embargo, dos años no fueron suficientes para restablecer la composición de especies de hormigas en ambos microhábitats en relación con las muestras del área control. Nuestro estudio es el primero en evaluar los efectos del fuego antrópico sobre las comunidades de hormigas epígeas y hipógeas; se destaca la importancia de la evaluación de diferentes microhábitats para detectar con mayor precisión los efectos de las alteraciones antrópicas en las comunidades biológicas. Las comunidades de hormigas son solo parcialmente afectadas por incendios y las epígeas son las más perjudicadas. Además, este estudio proporciona conocimientos que pueden ayudar a la creación de programas de manejo de la vegetación del Cerrado, lo que permite conservar este importante bioma brasileño.

Palabras clave: quema antrópica, Sabana brasileña, recuperación post incendio, conservación-bioindicadores.

\section{REFERENCES}

Andersen, A. N. (1991). Responses of ground-foraging ant communities to three experimental fire regimes in a savanna forest of tropical Australia. Biotropica, 23(4b), 575-585.
Andersen, A. N., Hertog, T., \& Woinarski, J. C. Z. (2006). Long-term fire exclusion and ant community structure in an Australian tropical savanna: congruence with vegetation succession. Journal of Biogeography, 33, 823-832.

Andersen, A. N., Woinarski, J. C. Z., \& Parr, C. L. (2012). Savanna burning for biodiversity: Fire management for faunal conservation in Australian tropical savannas. Austral Ecology, 37, 658-667.

Arnan, X., Rodrigo, A., \& Retana, J. (2006). Post-fire recovery of Mediterranean ground ant communities follows vegetation and dryness gradients. Journal of Biogeography, 33, 1246-1258.

Barlow, J., Gardner, T. A., Araujo, I. S., Bonaldo, A. B., Costa, J. E., Esposito, M. C., (...), \& Peres, C. A. (2007). Quantifying the biodiversity value of tropical primary, secondary and plantation forests. Proceedings of the National Academy of Sciences of the United States of America, 104, 18555-18560.

Bestelmeyer, B. T., Agosti, D., Leeanne, E., Alonso, T., Brandão, C. R. F., Brown, W. L., Delabie, J. H. C., \& Silvestre, R. (2000). Field techniques for the study of ground-living ants: an overview, description, and evaluation. In D. Agosti, J. D. Majer, T. Alonso, \& T. Schultz (Eds.), Ants: Standard Methods for Measuring and Monitoring Biodiversity (pp. 122-144). Washington: Smithsonian Institution.

Cardoso, Crispim, Rodrigues, \& Barioni-Júnior, (2003) Efeitos da queima na dinâmica da biomassa aérea de um campo nativo no Pantanal. Pesquisa Agropecuária Brasileira, 38(6), 747-752.

Castro, E. A., \& Kauffman, J. B. (1998). Ecosystem structure in the Brazilian Cerrado: a vegetation gradient of aboveground biomass, root mass and consumption by fire. Journal of Tropical Ecology, 14, 263-284.

Cerdá, X., Arnam, X., \& Retana, J. (2013). Is competition a significant hallmark of ant (Hymenoptera: Formicidae) ecology? Myrmecological News, 18, 131-147.

Cheli, G. H., \& Corley, J. C. (2010) Efficient Sampling of Ground-Dwelling Arthropods Using Pitfall Traps in Arid Steppes. Neotropical Entomology, 39(6), 912-917.

Chevan, A., \& Sutherland, M. (1991). Hierarchical partitioning. The American Statistican, 45, 90-96.

Cianciaruso, M. V., Silva, I. A., \& Batalha, M. A. (2008). Diversidades filogenética e funcional: Novas abordagens para a Ecologia de comunidades. Biota Neotropica, 9(3), 93-103.

Core Team R. (2013). R: A language and environment for statistical computing. $R$ Foundation for Statistical Computing, Vienna, Austria. ISBN 3-900051-07-0. Retrieved from http://www.R-project.org/

Dufrêne, M., \& Legendre, P. (1997). Species assemblages and indicator species: the need for a flexible 
asymmetrical approach. Ecological Monograph, 67, 345-366.

Fernández, F. (Ed). (2003). Introducción a las Hormigas de la región Neotropical. Colombia, Bogotá: Instituto de Investigación de Recursos Biológicos Alexander Von Humboldt.

Frazer, G. W., Canham, C. D., \& Lertzman, K. P. (1999). Gap Light Analyzer (GLA): Imaging sowftware to extract canopy structure and gap light transmission indices from true color fisheyephotographs, user manual and programdocumentation. Nova Iorque: Simon Fraser University, Burnaby, British Colombia and The Institute of Ecosystem Studies, Millbrook, New York.

Frizzo, T. L. M., Bonizário, C., Borges, M. P., \& Vasconcelos, H. L. (2011). Revisão dos efeitos do fogo sobre a fauna de formações Savânicas do Brasil. Oecologia Australis, 15(2), 365-379.

Guimarães, A. F., Lasmar, C. J., Querido, L. C. A., Tanure, F. T., \& Ribas, C. R. (2014) Extensive vs. semiintensive grazing systems - are ants sensitive to this difference? Regnellea Scientia, 1(2), 35-48.

Higgins, S., Bond, W. J., \& Trollope, W. S. W. (2000). Fire, resprouting and variability: a recipe for grasstree coexistence in savanna. Journal of Ecology, 88, 213-229.

Hoffmann, W. A., Orthen, B., \& Nascimento, P. K. V. (2003). Comparative fire ecology of tropical savanna and forest trees. Functional Ecology, 17, 720-726.

Huntley, B. J., \& Walker, B. H. (1982). Ecology of Tropical Savannas. Berlin: Springer-Verlag.

Kelly, L. T., Nimmo, D. G., Spence-Bailey, L. M., Haslem, A., Watson, S. J., Clarke, M. F., \& Bennett, A. F. (2011). Influence of fire history on small mammal distributions: insights from a 100 -year post-fire chronosequence. Diversity and Distributions, 17, 462-473.

MacGeoch, M. A., Rensburg, B. J. V., \& Botes, A. (2002) The verification and application of bioindicators: A case study of dung beetles in a savanna ecosystem. Journal of Applied Ecology, 39, 661-672.

Mistry, J. (1998). Decision-making for fire use among farmers in savannas: an exploratory study in the Distrito Federal, central Brazil. Journal of Environmental Management, 54, 321-334.

Moretti, M., Duelli, P., \& Obrist, M. K. (2006). Biodiversity and resilience of arthropod communities after fire disturbance in temperate forests. Oecologia, 149, 312-327.

Myers, N., Mittermeier, R. A., Mittermeier, C. G., Fonseca, G. A. B. D. A., \& Kent, J. (2000). Biodiversity hotspots for conservation priorities. Nature, 403, 853-858.
Niemi, G. J., \& McDonald, M. E. (2004). Application of ecological indicators. Annual Review of Ecology, Evolution, and Systematics, 35, 89-111.

Pacheco, R., \& Vasconcelos, H. L. (2012). Habitat diversity enhances ant diversity in a naturally heterogeneous Brazilian landscape. Biodiversity and Conservation, 21, 797-809.

Parr, C. L., \& Andersen, A. N. (2008). Fire resilience of ant assemblages in long-unburnt savanna of northern Australia. Austral Ecology, 33, 830-838.

Pereira, A., França H., \& Santos, J. E. dos. (2003). Método para avaliação da susceptibilidade da vegetação do Cerrado ao fogo em relação a indicadores antrópicos. Anais XI SBSR, INPE, 501-508.

Philpott, S. M., Perfecto, I., Armbrecht, I., \& Parr, C. L. (2010). Ant Diversity and Function in Disturbed and Changing Habitats. In L. Lach, C. L. Parr, \& K. L. Abbott (Eds.), Ant Ecology. Oxford: Oxford University Press.

Pivello, V. R. (2011). The use of fire in the Cerrado and Amazonian rainforests of Brazil: Past and Present. Fire Ecology, 7(1), 24-39.

Queiroz, A. C. M., Ribas, C. R., \& França, F. M. (2013). Microhabitat Characteristics That Regulate Ant Richness Patterns: The Importance of Leaf Litter for Epigaeic Ants. Sociobiology, 60(4), 367-373.

Rabello, A. M., Queiroz, A. C. M., Lasmar, C. J., Cuissi, R. G., Canedo-Junior, E. O., Schmidt, F. A., Ribas, C. R. (2015). When is the best period to sample ants in tropical areas impacted by mining and in rehabilitation process? Insectes Sociaux (Printed ed.), 62, 227-236.

Ramos-Neto, M. B., \& Pivello, V. R. (2000). Lightning Fires in a Brazilian Savanna National Park: Rethinking Management Strategies. Environmental Management, 26(6), 675-684.

Raven, P. H., Evert, R. F., \& Eichhorn, S. E. (2007). Biologia vegetal (7 ed). Rio de Janeiro: Guanabara Koogan.

Ribas, C. R., Campos, R. B. F., Schmidt, F. A., \& Solar, R. R. C. (2012). Ants as Indicators in Brazil: A Review with Suggestions to Improve the Use of Ants in Environmental Monitoring Programs. Psyche, 23.

Rivera-Lombardi, R. J. (2003). Estudo da recorrência de queimadas e permanência de cicatrizes do fogo em áreas selecionadas do cerrado brasileiro, utilizando imagens TM/Landsat. São José dos Campos: INPE, 172p. (INPE-12663-TDI/1006).

Rodrigo, A. \& Retana, J. (2006). Post-fire recovery of ant communities in Submediterranean Pinus nigra forests. Ecography, 29, 231-239.

Schmidt, F. A., \& Solar, R. R. C. (2010). Hypogaeic pitfall traps: methodological advances and remarks to improve the sampling of a hidden ant fauna. Insectes Sociaux, 3, 261-266. 
Schmidt, F. A., Ribas, C. R., \& Schoereder, J. H. (2013). How predictable is the response of ant assemblages to natural forest recovery? Implications for their use as bioindicators. Ecological Indicators, 24, 158-166.

Scherber, C., Eisenhauer, N., Weisser, W. W., Schmid, B., Voigt, W., Fischer, M., (...), \& Tscharntke, T. (2010). Bottom-up effects of plant diversity on multitrophic interactions in a biodiversity experiment. Nature, 468, 553-556.

Schowalter, T. D. (2006). Insect Ecology: An Ecosystem Approach. Oxford: Academic Press.

Silva, R. R., Feitosa, R. M., \& Eberhardt, F. (2007). "Reduced ant diversity along a habitat regeneration gradient in the southern Brazilian Atlantic Forest". Forest Ecology and Management, 240(1-3), 61-69.

Silveira, J. M., Barlow, J., Andrade, R. B., Louzada, J., Mestre, L. A., Lacau, S., Zanetti, R., Numata, I., \& Cochrane, M. A. (2013). The responses of leaf litter ant communities to wildfires in the Brazilian Amazon: a multi-region assessment. Biodiversity and Conservation, 22, 513-529.

Swengel, A. B. (2001). A literature review of insect responses to fire, compared to other conservation managements of open habitat. Biodiversity and Conservation, 10, 1141-1169.

Teixeira, M. C., Schoereder, J. H., Nascimento, J. T., \& Louzada J. N. C. (2005). Response of Ant Communities to Sand Dune Vegetation Burning in Brazil (Hymenoptera: Formicidae). Sociobiology, 45, 1-3.

Townsend, C. R., Begon, M., \& Harper, J. L. (2010). Fundamentos em ecologia ( $3^{\mathrm{a}}$ Ed.). São Paulo: Artmed.

Underwood, E. C., \& Fisher, B. L. (2006). The role of ants in conservation monitoring: If, when, and how. Biological Conservation, 132, 166-182.

Valentine, L. E., \& Schwarzkpf, O. P. F. L. (2009). Effects of Weed-Management Burning on Reptile Assemblages in Australian Tropical Savannas. Conservation Biology, 23, 1.

Van Breemen, N. \& Finzi, A. C. (1998). Plant-soil interactions: ecological aspects and evolutionary implications. Biogeochemistry, 42, 1-19.

Vasconcelos, H. L., Pacheco, R., Silva, R. C., Vasconcelos, P. B., Lopes, C. T., Costa, N. A., \& Bruna, E. M. (2009). Dynamics of the Leaf-Litter Arthropod Fauna Following Fire in a Neotropical Woodland Savanna. PLoS ONE, 4(11), 7762.

Vasconcelos, H. L., Frizzo, T. L. M., Pacheco, R., Maravalhas, J. B, Camacho, G. P., Carvalho, K. S., Koch, E. B. A., \& Pujol-Luz, J. R. (2014). Evaluating sampling sufficiency and the use of surrogates for assessing ant diversity in a Neotropical biodiversity hotspot. Ecological Indicators, 46, 286-292.

Wilson, E. O. (1976). Which are the most Prevalent Ant Genera? Studia Entomologica, 19, 1-4. 